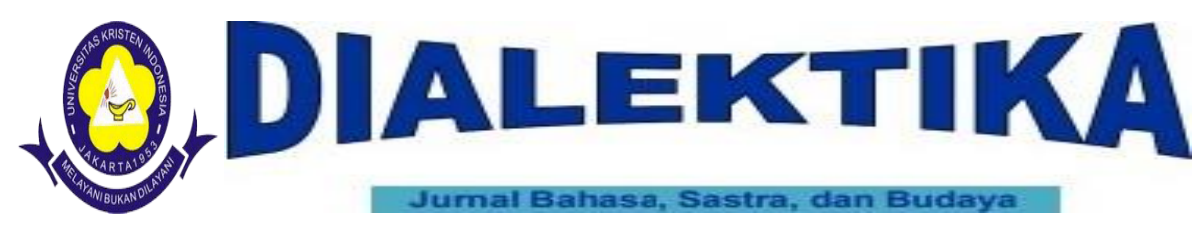

ISSN: 2338-2635

\title{
PENERJEMAHAN IDIOMATIS PETER NEWMARK DAN MILDRED LARSON
}

\author{
Yusniaty Galingging ${ }^{1}$, Gunawan Tambunsaribu ${ }^{2}$ \\ ${ }^{1,2}$ Program Studi Sastra Inggris, Fakultas Sastra dan Bahasa, \\ Universitas Kristen Indonesia \\ galinggingyusniaty@gmail.com*, gunawanreza_tamsar@yahoo.com
}

\begin{abstract}
Abstrak
Bidang penerjemahan pada era globalisasi ini merupakan pengetahuan yang sangat bermanfaat untuk dikuasai. Melalui penguasaan teori penerjemahan berbagai kajian terjemahan dapat dilakukan. Tulisan ini akan membicarakan dua penulis teori penerjemahan, yaitu Mildred Larson dan Peter Newmark. Kedua penulis ini membahas teori penerjemahan yang sering dirujuk pada mata kuliah penerjemahan oleh mahasiswa fakultas Sastra UKI. Dalam teorinya, ditemukan bahwa mereka menggunakan istilah yang sama, yaitu penerjemahan idiomatis. Istilah yang sama ini tidak secara serta merta dipahami mempunyai maksud yang sama, oleh karena itu perlu dikaji lebih dalam untuk mengetahui makna dari istilah tersebut. Apa yang dimaksud Larson dengan penerjemahan idiomatis dan yang dimaksud Newmark tidaklah sama. Tulisan ini dimaksudkan menguraikan istilah penerjemahan idiomatis oleh Newmark dan Larson dalam metode penerjemahan mereka. Menurut Larson, penerjemahan idiomatis adalah penerjemahan yang menggunakan bentuk gramatikal dan leksikal yang natural dari bahasa sasaran. Selain itu penerjemahan idiomatis merupakan penerjemahan yang harus dicapai oleh seorang penerjemah. Sementara itu, menurut Newmark penerjemahan idiomatis bukanlah tujuan yang harus dicapai oleh seorang penerjemah karena penerjemahan ini menggunakan katakata sehari-hari dalam terjemahannya dan juga menggunakan idiom-idiom yang tidak ditemukan pada teks sumber.
\end{abstract}

Kata kunci: penerjemahan, teori penerjemahan, penerjemahan idiomatis, metode penerjemahan, jenis-jenis penerjemahan.

\begin{abstract}
The field of translation in this globalization era is a very useful knowledge to be mastered. By mastering the translation theory, various translation studies can be carried out. This paper will discuss two authors of translation theory, namely Mildred Larson and Peter Newmark. These two authors discuss translation theory, often referred to in translation classes, in the Faculty of Letters of UKI. Both of them use the same term, namely idiomatic translation. This same term should not be automatically understood as to have the same purpose; therefore, it is necessary to understand the meaning of the term. What Larson meant by idiomatic translation and what Newmark meant were not equally the same. This paper is intended to describe the term idiomatic translation by Newmark and Larson in their translation theory. According to Larson, idiomatic translation is a translation that uses the natural grammatical and lexical forms of the target
\end{abstract}


language. Besides, idiomatic translation is a goal that a translator must achieve. Meanwhile, for Newmark, since this method uses colloquialisms and idioms that are not found in the original text, the idiomatic translation is not the translation's goal.

Keywords: translation, translation theory, idiomatic translation, translation methods, kinds of translation.

\section{Pendahuluan}

Peter Newmark dan Mildred Larson merupakan dua penulis buku teori penerjemahan yang digunakan di Fakultas Sastra Universitas Kristen Indonesia. Selama beberapa semester mata kuliah terjemahan merupakan mata kuliah kekhususan atau mata kuliah peminatan di Fakultas ini. Jumlah Satuan Kredit Semester (SKS) mencapai 20 sks dari 144 sks yang harus dilalui seorang mahasiswa untuk mencapai gelar Strata 1. Berkaitan dengan mata kuliah pengkhususan di fakultas ini ditemukan cukup banyak mahasiswa yang menulis kajian penerjemahan sebagai tugas akhir mereka. Secara kebetulan atau tidak, kedua pakar ini, baik Newmark maupun Larson menggunakan sebuah istilah yang sama, yaitu penerjemahan idiomatis. Kalau Peter Newmark menggunaka istilah ini sebagai bagian dari metode penerjemahan yang diuraikannya, Larson menggunakan istilah idiomatis sebagai bagian dari jenis-jenis penerjemahan yang dideskripsikannya.

Adanya penggunaan istilah yang sama pada teori penerjemahan kedua pakar tersebut, penulis merasa perlu menguraikan apa dan bagaimana maksud dan isi dari istilah yang sama ini. Dengan demikian mahasiswa dapat memahami secara benar isi dan penjelasan tentang istilah tersebut. Penulis dalam menguraikan teori dari kedua penulis ini akan mengikuti alur uraian kedua penulis ini demikian juga contoh-contoh yang mereka gunakan. Tujuannya adalah menghindarkan penyimpangan dari apa yang dimaksud oleh kedua pakar tersebut. Selain itu, tulisan ini diharapkan agar mahasiswa tidak ragu-ragu menggunakan istilah idiomatis dalam kajian penerjemahan mereka, atau juga menggunakannya dalam penelitian yang mahasiswa lakukan dengan benar.

Secara khusus tulisan ini memang diharapkan dapat membantu mahasiswa dalam memahami teori penerjemahan Peter Newmark dan Mildred Larson tetapi tulisan ini juga tentunya terbuka bagi siapa saja yang tertarik mendalami teori penerjemahan khususnya memahami jenis-jenis dan metode penerjemahan yang dibahas oleh kedua penulis buku teori penerjemahan ini. Oleh karena itu, tulisan ini seluruhnya ditulis 
berdasarkan buku Peter Newmark yang berjudul "A Textbook of Translation" edisi pertama (1988) dan buku Mildred Larson yang berjudul "Meaning-based Translation, A Guide to Cross-Language Equivalence", edisi kedua (1984).

Istilah metode penerjemahan dan jenis-jenis penerjemahan pada dasarnya mempunyai makna yang berbeda. Berdasarkan Kamus Besar Bahasa Indonesia metode adalah cara kerja yang bersistem untuk memudahkan pelaksanaan sesuatu kegiatan guna mencapai tujuan yang ditentukan. Sedang kata jenis-jenis adalah macam-macam atau rupa-rupa. Kalau dikatakan jenis-jenis penerjemahan tentunya adanya berbagai macam penerjemahan. Akan tetapi, kalau dilihat lebih detail pada teori penerjemahan Newmark dan Larson, meskipun mereka menggunakan istilah yang berbeda, yaitu Newmark menggunakan istilah metode, dan Larson mengunakan istilah jenis-jenis penerjemahan namun keduanya merujuk pada bentuk-bentuk penerjemahan baik proses penerjemahannya maupun hasil penerjemahan itu. Untuk itu penulis akan menguraikan terlebih dahulu masing-masing apa yang dikatakan Newmark sebagai metode terjemahan dan yang dimaksud Larson dengan jenis-jenis penerjemahan.

\section{Teori Penerjemahan Newmark}

Pada bagian ini akan diuraikan teori penerjemahan menurut Peter Newmark. Selain menjelaskan hal-hal tentang apa itu penerjemahan menurut Newmark, bagian ini akan secara khusus menguraikan metode penerjemahan Newmark.

Menurut Newmark, penerjemahan adalah menerjemahkan makna dari sebuah teks ke dalam Bahasa lain sebagaimana yang dimaksudkan oleh penulis teks tersebut. (...it is rendering the meaning of a text into another language in the way that the author intended the text.) (Newmark, 1988: 5) Dalam pengantarnya Newmark menyampaikan bahwa masalah utama dalam penerjemahan adalah apakah akan menerjemahkan secara literal, dalam arti harafiah atau menerjemahan secara bebas. Untuk ini istilah yang digunakan Newmark adalah freely. Perdebatan terhadap kedua istilah ini, 'harafiah' dan 'bebas' telah dimulai sejak abad pertama yang terus berlangsung hingga abad ke-19. Bagi kelompok yang menganut penerjemahan ‘bebas' berargumen bahwa penerjemahan itu yang penting adalah spiritnya, bukan kata-katanya. Mereka juga mengatakan yang lebih penting adalah maknanya bukan kata-katanya, atau kalimat-kalimat yang digunakan. (Newmark 1988: 45) 
Akan tetapi terhadap perdebatan tersebut, Newmark mengatakan bahwa hal tersebut adalah masalah teoritis yang tidak menyentuh masalah mendasar seperti, apa yang menjadi tujuan penerjemahan, siapa yang membaca penerjemahan itu dan juga jenis teks yang digunakan. Terhadap hal tersebut maka Newmark membentuk diagram V untuk mengatasi masalah-masalah mendasar pada penerjemahan, sebagai berikut:

Penekanan pada BSu

$\underline{\text { Word-for-word translation }}$

Literal translation

$\underline{\text { Faithful translation }}$

Semantic translation.

\section{Penekanan pada BSa}

\section{$\underline{\text { Adaptation }}$}

$\underline{\text { Free translation }}$

Idiomatic translation

Communicative translation

Diagram 1 (Newmark, 1988: 45)

\subsection{Metode Penerjemahan Newmark}

Newmark dalam Newmark 1988: 45-48 membagi 8 metode penerjemahan, sebagai berikut:

\section{a. Penerjemahan kata per-kata (word-for-word translation)}

Kalau dilihat pada diagram V yang dibuat Newmark, metode ini berada pada bagian penerjemahan yang bertekanan pada Bahasa Sumber (BSu). Maksudnya adalah penerjemahan yang dilakukan dengan mempertahankan unsur-unsur atau bentuk BSu. Bentuk yang dimaksud dalam hal ini adalah bentuk gramatika, frasa, klausa, kalimat dan urutan kata atau hal-hal yang bertalian dengan unsur linguistik $\mathrm{BSu}$.

Pada metode penerjemahan kata per-kata ini, penerjemah oleh karena mempertahankan kata-demi-kata BSu sehingga tidak memperhatikan konteks. Terhadap kata-kata yang bersifat kultural pada metode ini diterjemahkan secara harafiah saja. Oleh karena itu penerjemahan seperti ini berguna untuk mengetahui mekanisme BSu atau metode ini digunakan sebagai proses awal dari penerjemahan atau pre-translation terhadap teks yang sulit. 


\section{b. Penerjemahan harafiah (Literal translation)}

Pada metode ini dilakukan beberapa penyesuaian. Stuktur BSu tentunya berbeda dengan struktur Bahasa Sasaran (BSa). Maka susunan gramatikal BSu dikonversi ke bentuk gramatikal BSa. Akan tetapi kosa katanya masih tetap diterjemahan secara kata per-kata dan tidak dikaitkan dengan konteks. Metode penerjemahan ini digunakan untuk penerjemahan awal yang mulai memecahkan masalah-masalah gramatikal yang ditemukan pada teks sumber.

\section{c. Penerjemahan Setia (Faithful translation)}

Pada metode ini yang dilakukan adalah menghasilkan terjemahan yang secara ketat mereproduksi makna kontektual dari teks sumber. Metode ini mengabaikan struktur BSa. Pada metode penerjemahan ini kata-kata yang bersifat kultural ditransfer ke BSa tetapi dengan menggunakan bentuk gramatikal yang tidak sesuai dengan BSa demikian juga bentuk leksikalnya. Kemudian pada metode ini penerjemah berusaha untuk sepenuhnya setia dengan maksud penulis teks sumber. Oleh karena itu, metode ini disebut dengan penerjemahan setia.

\section{d. Penerjemahan semantis (Semantic Translation)}

Metode penerjemahan semantis pada dasarnya masih sama dengan metode penerjemahan setia (faithful translation). Titik perbedaannya hanya dalam hal nilai estetikanya saja. Keindahan dan nada yang natural menjadi perhatian khusus pada penerjemahan semantis. Pada metode ini penyesuaian makna dilakukan agar tidak mengulang-ulang nada-nada yang sama pada hasil terjemahannya. Kemudian, terhadap istilah kultural diterjemahkan dengan kata yang tidak bersifat kultural atau dengan menggunakan istilah-istilah fungsional yang bukan merupakan padanannya. Contoh yang diberikan Newmark dalam Bahasa Perancis une onne repassant un corporal yang dalam Bahasa Inggris adalah a nun ironing a corporal cloth (seorang biarawati menyeterika pakaian Kopral). Intinya, penerjemahan semantis lebih fleksibel, lebih kreatif dan penerjemah dapat menggunakan intuisinya dan rasa empati penerjemah terhadap teks sumber.

\section{e. Adaptasi (Adaptation)}


Menurut Newmark, metode ini merupakan metode penerjemahan yang paling bebas. Penerjemahan ini utamanya digunakan untuk menerjemahkan drama khususnya komedi. Selain itu juga digunakan untuk menerjemahkan puisi. Metode ini mempertahankan tema, karakter, dan alur cerita. Kemudian, dalam hal-hal kultur Bahasa sumber dikonversikan ke kultur Bahasa sasaran. Selain itu, drama atau puisi diterjemahkan secara literal dan ditulis kembali dengan mendramatisir. Pada puisi banyak dilakukan adaptasi yang digunakan secara tidak tepat.

\section{f. Penerjemahan bebas (free Translation)}

Metode penerjemahan bebas, sesuai dengan judulnya dikatakan sebagai penerjemahan yang tidak mengikuti bentuk originalnya. Bentuknya biasanya parafrase, oleh karena itu hasil terjemahan dari metode penerjemahan ini lebih panjang dari teks aslinya dan berpretensi, yaitu dimaksudkan untuk tujuan-tujuan tertentu. Oleh karena itu metode ini oleh Newmark tidak dianggap sebagai penerjemahan.

\section{g. Penerjemahan idiomatis (Idiomatic Translation)}

Metode penerjemahan idiomatis ini mereproduksi pesan yang ada pada Bahasa sumber tetapi cenderung merusak nuansa makna teks sumber karena menggunakan kata-kata sehari-hari dan juga idiom-idiom yang tidak ditemukan pada teks sumber. Dengan kata lain, pada teks sumber tidak menggunakan idiom dalam menyampaikan maksud penulis tetapi pada terjemahannya menggunakan idiom.

\section{h. Penerjemahan komunikatif (Communicative Translation)}

Pada metode penerjemahan komunikatif penerjemah berusaha menerjemahkan secara persis makna kontekstual dari teks sumber. Penerjemah berusaha mempertahankan isi teks sumber dengan menggunakan bahasa yang dipahami pembaca dan pengguna terjemahan itu.

\subsection{Penerjemahan Semantis dan Penerjemahan Komunikatif}


Setelah menguraikan kedelapan metode sebagaimana yang telah diuraikan di atas, Newmark memberi komentar terhadap metode terjemahan tersebut. Akan tetapi komentar yang dibuatnya tidak terhadap seluruh metode-metode penerjemahannya, tetapi secara khusus hanya pada metode penerjemahan semantis dan komunikatif. Newmark menjelaskan bahwa menurutnya ada dua tujuan utama penerjemahan, yaitu penerjemahan itu harus bersifat ekonomis dan yang kedua harus memiliki akurasi yang baik. Kedua tujuan ini dipenuhi oleh penerjemahan semantis dan penerjemahan komunikatif. Yang dimaksud Newmark dalam hal ekonomis adalah penerjemahan yang tidak berpanjang-panjang, tidak berputar-putar tetapi menggunakan kata-kata yang sesuai yang tepat untuk makna yang dimaksud oleh teks sumber. Penerjemahan semantis ditulis berdasarkan kemampuan linguistik penulisnya sedang penerjemahan komunikatif mengarah kepada kepentingan pengguna terjemahan itu atau pembacanya.

Selain ada dua tujuan utama, Newmark juga mengutarakan adanya dua jenis teks terjemahan, yaitu teks ekspresif dan teks informatif vokatif. Metode penerjemahan semantis biasanya digunakan untuk menerjemahkan teks yang ekspresif dan teks informatif vokatif diterjemahkan dengan metode penerjemahan komunikatif. Teks yang ekspresif menurut Newmark, yaitu teks yang mengandung komponen-komponen yang ekspresif, seperti teks yang unsur sintaksisnya tidak umum, kolokasi, metafora, juga teks yang mengunakan kata-kata yang tidak biasa, dan neologisme. Untuk menerjemahkan teks seperti ini digunakan metode penerjemahan semantis. Terhadap istilah tehnis, metafora yang sudah tidak digunakan lagi (dead metaphors), kolokasi yang sering digunakan, slang, kata-kata sehari-hari, dan bahasa sehari-hari diterjemahkan dengan menggunakan metode penerjemahan semantis dan juga metode penerjemahan komunikatif.

Ciri lain lagi dari penerjemahan semantis adalah bahwa penerjemahan semantis ini bersifat personal yang mengikuti proses pemikiran dari penulis teks sumber. Kemudian, metode ini dalam menerjemahkan cenderung berlebihan karena berupaya menuangkan nuansa makna yang ada pada teks sumber, namun malah menghilangkan maknanya karena berusaha menghasilkan makna pragmatis. Berbeda dengan penerjemahan komunikatif penerjemahan ini bersifat sosial, berkonsentrasi pada pesan yang ada pada teks sumber. Namun, karena ditulis seadanya, maka akibatnya terjemahan ini dianggap terjemahan yang kurang tepat. Ada satu hal lagi yang dikatakan 
Newmark terhadap penerjemahan semantis dan komunikatif, yaitu bahwa penerjemahan komunikatif biasanya lebih bagus dari teks aslinya dibanding dengan mengunakan metode penerjemahan semantis. (Newmark, 1988: p. 47-48)

Newmark banyak secara detail menguraikan ciri-ciri dan karakter metode penerjemahan semantis dan komunikatif secara rinci, namun beliau mengatakan bahwa kedua metode inilah yang memenuhi dua tujuan utama penerjemahan, yaitu keakuratan dan keekonomisan. Sehingga kedua metode ini seharusnya digunakan secara bersamasama dalam melakukan penerjemahan.

\section{Teori Perjemahan Larson}

Sebagaimana Newmark, Larson dalam teorinya menjelaskan jenis-jenis terjemahan. Penerjemahan menurut Larson dapat dibagi menjadi dua kelompok utama, yaitu penerjemahan literal atau penerjemahan harafiah (literal) dan penerjemahan idiomatis (Idiomatic). Yang dimaksudkan oleh Larson pada penerjemahan idiomatis adalah penerjemahan yang berdasarkan makna atau yang bertekanan pada makna yang ada pada BSu, dan mengekspresikannya dengan menggunakan struktur dan kosa kata Bahasa sasaran. Sedang penerjemahan harafiah adalah penerjemahan yang bertekanan pada BSu atau yang mempertahankan bentuk BSu. Penerjemahan literal adalah penerjemahan kata-demi-kata. Penerjemahan literal sering menghilangkan makna yang ada pada teks sumber karena mempertahankan gramatika dan tidak menyesuaikan dengan konteks. Penerjemahan jenis ini pada dasarnya hanya berguna untuk mempelajari ciri-ciri linguistik bahasa sumber. Apabila ditujukan untuk melakukan penerjemahan cara ini dapat menyesatkan karena memaksakan bentuk Bsu ke BSa sehingga makna yang ada dalam BSu tidak dapat disampaikan dalam BSa.

\subsection{Rentang Penerjemahan Larson}

Pada uraian Larson (Larson 1884: 17-20) dalam menjelaskan jenis-jenis penerjemahan, Larson memberikan bagan rentang jenis-jenis penerjemahan. Rentang ini dimulai dari sangat literal (very literal) hingga sangat bebas (unduly free translation), seperti pada bagan di bawah ini: 


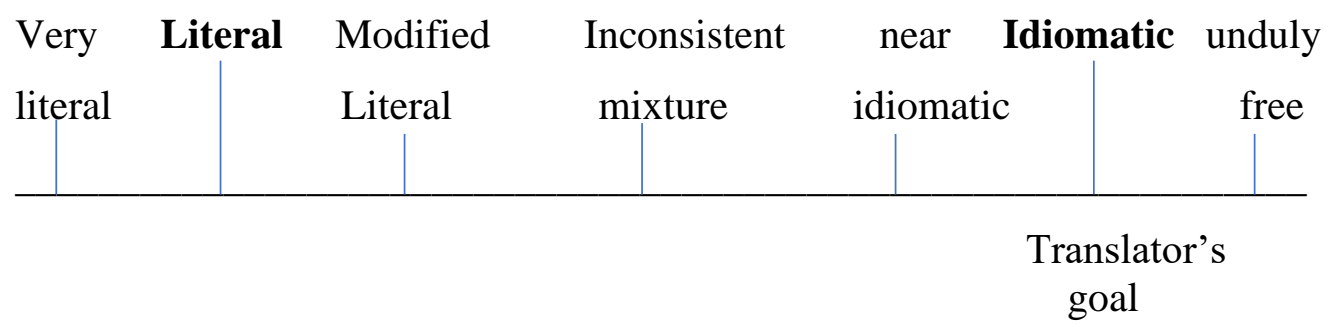

Bagan 2: (Larson, 1984:19)

Terhadap rentang penerjemahan ini Larson tidak menjelaskan satu persatu dari jenis-jenis terjemahan yang disebutkannya. Keterangan yang diberikan hanya bertekanan pada dua jenis penerjemahan yang telah dijelaskan terlebih dahulu, yaitu penerjemahan literal dan penerjemahan idiomatis. Kalau dilihat pada bagan di atas keduanya ditulis dalam cetak tebal yang terletak pada titik kedua di ujung kiri dan titik kedua di ujung kanan.

Bagan dari rentang penerjemahan Larson diawali dengan jenis penerjemahan Very Literal, yaitu penerjemahan yang sangat harafiah. Dari penerjemahan yang sangat harafiah menjadi penerjemahan harafiah atau Literal. Dari penerjemahan literal menjadi penerjemahan literal yang dimodifikasi atau Modified Literal. Dari sini kemudian menjadi penerjemahan yang bercampur-campur secara tidak konsisten (inconsistence mixture). Setelah itu, masuk kepada penerjemahan yang mendekati idiomatis (near idiomatic) kemudian menjadi penerjemahan idiomatis dan selanjutnya penerjemahan yang sangat bebas (unduly free).

Rentang penerjemahan Larson adalah sebagai berikut:

\subsubsection{Penerjemahan Sangat Literal (Very Literal)}

Untuk penerjemahan yang sangat harafiah ini menurut Larson menyebutnya sebagai penerjemahan interlinier, yaitu penerjemahan yang dilakukan kata per-kata, susunannya dan urutannya dipertahankan secara ketat. Penerjemahan seperti ini dapat dilakukan khususnya terhadap bahasa dari rumpun yang sama dan dimaksudkan untuk tujuan tertentu saja, seperti untuk mempelajari atau mengetahui ciri-ciri linguistik bahasa sumber. Maka dapat dikatakan, penerjemahan yang sangat literal ini bukan ditujukan untuk menghasikan penerjemahan pada umumnya, tetapi hanya untuk kebutuhan mengenal struktur atau hal-hal yang berkaitan dengan konstruksi Bahasa sumber. 
Kemudian apa yang dimaksud Larson dengan penerjemahan literal? Untuk memperjelas hal ini Larson memberi contoh penerjemahan literal sebagai berikut: Kan daro (Bahasa Chuave) yang maknanya dalam bahasa Inggris 'What is your name?' (Siapa nama kamu?). Kalau diterjemahkan secara literal ke Bahasa Inggris menjadi 'your-name call'. Melihat hasil terjemahan itu tentunya pengertiannya berbeda dari yang dimaksudkan BSu. Dari contoh ini dapat dilihat 'kan' berarti your-name dan daro berarti 'call'. Berarti kalau diterjemahkan secara literal akan menjadi your-name call 'nama kamu memanggil'. Makna dari terjemahan ini tentunya sangat jauh dari yang dimaksudkan BSu bahkan sangat sulit untuk dipahami.

\subsubsection{Penerjemahan Modifikasi Literal (Modified Literal)}

Pada jenis penerjemahan literal yang dimodifikasi (modified Literal) ini, Larson mencontohkan dengan menggunakan Bahasa Papua Nugini, yaitu: ro ahombo ngusifu pamariboyandi. Ro adalah 'I', ahombo 'her', ngusifu 'heart' pamariboyandi 'Ifastened-her'. Sehingga, kalau diterjemahkan secara literal menjadi 'I her heart Ifastened-her'. Tetapi, pada penerjemahan literal yang dimodifikasi terjemahannya adalah 'I fastened her in my heart'. Hasil terjemahan ini sebenarnya belum memberikan makna yang sebenarnya. Makna sebenarnya adalah 'I never forget her'. Akan tetapi pada penerjemahan literal yang dimodifikasi dapat dilihat adanya penyesuaian bentuk, bukan lagi I her heart I-fastened-her tetapi telah menjadi I fastened her in my heart. Kalau dibandingkan dengan penerjemahan literal maka pada penerjemahan literal yang dimodifikasi ini pembaca sudah lebih bisa memahaminya.

Menurut Larson, pada model penerjemahan seperti ini yang disesuaikan adalah gramatikanya apabila sangat diperlukan. Maksudnya adalah apabila bentuk gramatikanya sangat jauh berbeda dari gramatika Bahasa sasaran barulah disesuaikan. Tetapi pada kata-kata pilihan penerjemah maka akan mengikuti bentuk Bahasa sumber. Oleh karena itu, penerjemahan literal yang dimodifikasi ini hasil terjemahannya tidak natural, bahkan Larson menyebutkannya dengan terjemahan yang salah. (Larson, 1984: 18).

\subsubsection{Penerjemahan Bercampuran Tidak Konsisten (Inconsistent Mixture)}


Lantas, bagaimana dengan penerjemahan inconsistent mixture atau penerjemahan bercampuran yang tidak konsisten? Secara khusus tidak dijelaskan dan tidak diberi contoh oleh Larson. Tetapi, pada penjelasannya dapat dipahami bahwa pada jenis penerjemahan ini maksudnya adalah pada bagian tertentu bentuk dan makna sudah sesuai dengan BSa tetapi pada bagian yang tidak dipahami dengan sepenuhnya oleh sipenerjemah maka akan ditinggalkan begitu saja atau mengikuti bentuk BSu saja.

Intinya pada jenis penerjemahan bercampuran yang tidak konsisten ini, sebahagian teks sumber disesuaikan sedemikian rupa untuk menghindarkan ketidakjelasan atau terjemahan yang tidak masuk akal, tetapi pada bagian yang sulit dipahami penerjemah diterjemahkan secara literal.

\subsubsection{Penerjemahan Mendekati Idiomatis (Near Idiomatic)}

Pada jenis penerjemahan ini dapat dilihat bahwa sudah dilakukan banyak penyesuaian sehingga terjemahan ini sudah semakin mendekati penerjemahan berdasarkan makna atau penerjemahan idiomatis. Berbagai penyesuaian seperti penyesuaian gramatika dan kosa kata sudah dilakukan, demikian juga dengan konteks gramatika dan konteks budayanya. Hanya saja disana-sini masih terkesan bahwa teks itu adalah teks terjemahan. Dikatakan demikian oleh karena menurut Larson penerjemahan idiomatis itu tidak lagi dirasakan sebagai teks terjemahan tetapi sudah seperti teks aslinya.

\subsubsection{Penerjemahan Idiomatis (Idiomatic Translation)}

Pada penerjemahan idiomatis ini, Larson mengatakan jenis penerjemahan ini telah menggunakan bentuk yang natural atau bentuk yang paling lazim dan biasa digunakan dalam BSa, baik strukturnya dan juga pilihan-pilihan kata yang digunakan. Penerjemahan yang betul-betul idiomatis hasil terjemahannya tidak lagi seperti sebuah terjemahan, tetapi sudah seperti teks original. Itulah sebabnya Larson mengatakan penerjemahan idiomatislah yang harus dicapai dalam melakukan penerjemahan. Inilah yang menjadi tujuan penerjemahan Larson, yaitu menghasilkan penerjemahan idiomatis.

Lebih jauh lagi Larson mengatakan tujuan penerjemahan adalah menghasilkan teks dalam BSa yang mengkomunikasikan pesan yang sama dengan pesan yang ada 
pada teks BSu, tetapi sudah menggunakan struktur BSa dan juga sudah menggunakan bentuk leksikal BSa. (The translator's goal should be to reproduce in the receptor language a text which communicates the same messages as the source language but using the natural grammatical and lexical choices of the receptor language. Larson 1984: 19)

Untuk memperjelas apa yang dimaksud Larson dengan penerjemahan idiomatis, dapat dilihat pada contoh penerjemahan idiomatis berikut.

Seorang perawat berkata kepada seorang pasien yang masih kecil:

"It's time for us to take our medicine now"

Secara harafiah kalimat ini artinya adalah:

'Sekarang waktunya kita makan obat'

Pronomina us 'kita' pada kalimat ini merujuk pada perawat sebagai pembicara dan anak kecil itu sebagai teman bicara. Dari kalimat ini kalau diterjemahkan secara harafiah, artinya perawat dan pasien itu akan makan obat. Tetapi makna yang dimaksud pada BSu bukanlah demikian, si perawat tentunya tidak ikut makan obat karena dia bukan pasien. Penggunaan pronomina us pada kalimat ini merupakan cara perawat berempati pada pasien tersebut. Maka penerjemahan idiomatis sesuai dengan maksud kalimat BSu adalah:

"Sekarang waktunya kamu makan obat."

Sekalipun Larson menyatakan bahwa tujuan penerjemahan adalah menghasilkan terjemahan idiomatis, tetapi Larson juga menyadari bahwa untuk mencapai terjemahan idiomatis tersebut tidaklah mudah akibatnya terjadi penerjemahan yang bercampurcampur dengan jenis penerjemahan lainnya, seperti penerjemahan yang mendekati idiomatis (near idiomatic translation) dan sebagainya.

Penggunaan istilah idiomatis oleh Larson ini didasari dari apa yang mendasari hakekat dari idiom itu sendiri. Idiom terdiri dari serangkaian kata atau gabungan kata. Namun makna dari idiom tersebut tidak diperoleh dari masing-masing kata yang ada pada rangkaian kata itu tetapi dari keseluruhan rangkaian kata tersebut. Contohnya idiom bull-headed artinya stubborn (keras kepala), makna stubborn tidak diambil dari kata bull atau kata headed.

\subsubsection{Penerjemahan Sangat Bebas (Unduly Free Translation)}


Pada jenis penerjemahan yang sangat bebas ini, Larson tidak mengkategorikannya sebagai sebuah penerjemahan. Menurut Larson, penerjemahan tidak boleh menambahkan hal-hal atau makna yang tidak ada pada teks sumbernya. Penerjemahan jenis ini, disebutkan sebagai penerjemahan yang sangat bebas karena penerjemahan ini menambah-nambahkan hal yang tidak ditemukan atau disebutkan pada BSu. Akibatnya penerjemahan ini tidak lagi sama dengan makna yang ada pada BSu. Penerjemahan jenis ini umumnya dilakukan untuk tujuan humor atau untuk mendapat kesan tertentu pada BSa.

\section{Penerjemahan Idiomatis Peter Newmark dan Mildred Larson}

Dari uraian di atas dapat dilihat bahwa apa yang dimaksud Newmark dan apa yang dimaksud Larson dengan penerjemahan idiomatis tidak ada kesamaannya sama sekali. Perbedaan keduanya dapat dilihat sebagai berikut:

a. Berdasarkan hasil terjemahan.

Penerjemahan idiomatis bukanlah hasil penerjemahan yang harus dicapai bagi Newmark tetapi bagi Larson, penerjemahan idiomatis adalah hasil terjemahan yang harus dicapai.

b. Berdasarkan tujuan penerjemahan.

Bagi Larson, penerjemahan idiomatis adalah tujuan dari penerjemahan, tetapi menurut Newmark tujuan penerjemahan adalah gabungan antara penerjemahan semantis dan penerjemahan komunikatif. Karena kedua metode inilah yang memenuhi dua tujuan penerjemahan, yaitu ekonomis dan akurat.

c. Berdasarkan penggunaan bentuk leksikal.

Penerjemahan idiomatis menurut Newmark menggunakan kosa-kata seharihari yang dapat berakibat menjadi kurang serius dan juga adanya penggunaan idiomidom yang tidak ada pada teks sumber. Menurut Larson, penerjemahan idiomatis telah menggunakan kosa kata yang sesuai atau yang natural pada BSa, sehingga penerjemahan jenis ini tidak lagi dirasakan sebagai sebuah penerjemahan tetapi seperti teks original.

d. Berdasarkan struktur gramatikal.

Newmark tidak menjelaskan bentuk gramatikal dari metode penerjemahan idiomatis. Sedangkan Larson, dengan jelas mengatakan bahwa pada penerjemahan 
idiomatis struktur gramatikal BSu sudah disesuaikan dengan struktur gramatikal BSa. Dengan demikian pengguna atau pembaca dari teks terjemahan itu dapat memahami sepenuhnya pesan atau ide yang ada pada BSu.

e. Berdasarkan maknanya.

Newmark mengatakan pada penerjemahan idiomatis makna yang ada pada teks sumber diterjemahkan ke BSa tetapi terjadi berbagai distorsi oleh karena pilihan kosa kata yang digunakan. Pada penerjemahan idiomatis Larson, makna yang ada pada teks sumber disampaikan dengan menggunakan kosa kata dan gramatikal yang ada pada BSa, sehingga pembaca teks terjemahannya dapat memahami sebagaimana makna yang ada pada teks sumber.

\section{Kesimpulan}

Dari uraian di atas hal pertama yang dapat diungkapkan adalah ada kesamaan antara keduanya dalam menguraikan teori mereka. Meskipun Newmark menggunakan istilah metode penerjemahan terhadap teorinya dan Larson menggunakan istilah jenisjenis penerjemahan dalam teorinya akan tetapi dapat dengan jelas dilihat kesamaan antara keduanya. Pada dasarnya mereka memberikan deskripsi mengenai tahapantahapan dalam melakukan penerjemahan atau proses penerjemahan, mulai dari penerjemahan yang masih mentah, yaitu menerjemahkan kata-demi-kata hingga penerjemahan yang sangat bebas.

Penggunaan istilah idiomatis oleh Newmark dan Larson jelas berbeda. Metode penerjemahan idiomatis menurut Newmark bukanlah tujuan yang akan dicapai dari penerjemahan itu karena pada penerjemahan ini mengunakan kata-kata sehari-hari dan menggunakan idiom-idiom yang tidak digunakan pada teks sumber. Bagi Larson, tujuan penerjemahan adalah mencapai penerjemahan idiomatis, penerjemahan yang tidak diperoleh dari kata-demi-kata tetapi dari gabungan makna yang ada dari kata-kata dan struktur gramatikal yang digunakan yang sesuai dengan struktur BSa.

Dengan demikian, tulisan ini dapat memberikan pemahaman tentang penggunaan istilah yang sama dalam teori penerjemahan namun mempunyai makna yang berbeda. Penulis mengharapkan bagi yang berminat membuat kajian penerjemahan tidak terjebak dalam penggunaan istilah saja tetapi harus juga 
memperhatikan siapa yang menggunakan istilah tersebut dan apa yang dimaksud dengan istilah itu.

\section{Daftar Pustaka}

Cook, Guy. 2010. Translation in Language Teaching. New York: Oxford University Press

Katan, David. 1999. Translating Culture. An Introduction for Translators, Interpreters and Mediators. United Kingdom: St. Jerome Publishing.

Kridalaksana, H. 1993. Kamus Liguistik. Jakarta: Gramedia Pustaka.

Larson, L. Mildred. 1984. Meaning-Based Translation. A Guide to Cross-Language Equivalence. $2^{\text {nd }}$ Ed. New York: University Press of America.

Nababan, M.R. 1997. Aspek Teori Penerjemahan dan Pengalihbahasaan. Surakarta: PPS UNS.

Newmark. Peter. 1988. A Textbook of Translation. $1^{\text {st }}$ ed. Great Britain: Prentice-Hall International.

Nida, E.A \& Charles R, T. 1969. The Theory and Practice of Translation. Leiden: E.J.Brill.

Nida, E.A. 1975. Componential Analysis of Meaning. An Introduction to Semantic Structures. Netherland: Mountain \& Co. Publisher

Laman Acuan:

https://www.kbbi.web.id (2021, Juni 10) 